Stout, J. D. (1955). J. gen. Microbiol. 12, 237-240

\title{
The Effect of Partial Steam Sterilization on the Protozoan Fauna of a Greenhouse Soil
}

\author{
By J. D. STOUT* \\ Department of Zoology, Victoria University College, Wellington, New Zealand
}

SUMMARY: Comparison of the cultures from treated and untreated greenhouse soil showed that partial steam sterilization decreased the number of protozoan species, delayed the development of the fauna, but favoured the growth of the surviving ciliate species. This was particularly true of the treated topsoil.

In 1909 Russell \& Hutchinson put forward the view that 'sick' soils owed their infertility to low bacterial activity, that bacterial activity was inhibited by some factor which was removed by partial sterilization, and that this inhibitory factor was the protozoan fauna. It is now realized, however, that partial sterilization, particularly by steam injection, has widespread effects on the soil equilibrium and that no one factor is sufficient to explain its beneficial effects (Anon., 1948). It is recognized that the total effect of steaming soil is more extensive than its biological effect alone and that physical and chemical characteristics of the soil are also changed. These include water-holding capacity, capillary properties, destruction of the colloidal film surrounding soil particles, increased concentration of the soil solution, and increased solubility of soil constituents (e.g. Ca, Mg, Mn, phosphate). The biological effects are an initial inhibition of bacterial activity, and seed germination followed by greatly stimulated bacterial and plant growth.

Singh \& Crump (1953) examined the effect of partial sterilization on the numbers of amoebae in a field soil. In the present paper, the results of which agree generally with their findings, I am concerned with the effect of partial steam sterilization on the number of species in the samples and on ciliate growth.

\section{METHODS}

The samples examined were from a greenhouse soil at the Cawthron Institute which had been used for growing tomatoes. The soil was sterilized by steam injection to a depth of $18 \mathrm{in}$. by pipes inserted from above. Samples were taken 100 days later from the topsoil (0-4 in.) and subsoil (20-24 in.) of both treated and untreated soil. These samples were cultured 24 days later, in the following way and the development of the protozoan fauna followed.

Sterile $10 \mathrm{~cm}$. Petri dishes were used with a plain agar base. A sample of soil $(10 \mathrm{~g}$.) was added to the side of a dish and then $20 \mathrm{ml}$. sterile water; incubation was at room temperature $\left(c .18^{\circ}\right)$. For examination a plate was

* Present address: Soil Bureau Experimental Station, Eastern Hutt Road, Lower Hutt, New Zealand. 
placed on the microscope stage and examined with the aid of low power and water-immersion lenses. Species were identified morphologically and the growth of the protozoan fauna followed in this way.

\section{RESULTS}

The cultures were set up on 11 October. After 1 day there was little protozoan activity; Saprophilus spp. appeared in the untreated topsoil culture and Vorticella striata in the untreated subsoil culture. After 2 days, flagellates were omnipresent, but whereas the treated subsoil showed no ciliates and the treated topsoil only a few Colpoda inflata, the untreated samples showed a number of species. The subsoil had $C$. inflata, $C$. steinii, Saprophilus spp., and a rotifer. The topsoil had these three ciliate species, together with Oxytricha pellionella, Chilodonella sp., and nematodes.

After 3 days, the treated subsoil had Colpoda inflata, and the treated topsoil added Oxytricha pellionella to its fauna as did the untreated subsoil. At this time the untreated topsoil was readily distinguishable by the greater variety of species present and still more by the greater number of individuals, especially Colpoda inflata and $C$. steinii, which far exceeded the numbers present in the other cultures.

After 11 days, Chilodonella, Oxytricha, Vorticella, Euplotes and Trichopelma spp. were noted in the untreated topsoil, the two Colpoda spp. having disappeared. In the untreated subsoil Oxytricha, Vorticella, Enchelys, Mayorella and Sphenoderia spp. were present. In the treated subsoil Colpoda inflata, Oxytricha and Vorticella spp. were present, while in the treated topsoil there were only two ciliate species, Colpoda inflata and Oxytricha sp. These were present, however, in very great numbers. With a lens combination L.P. $\times 10$, up to 100 individuals could be observed in one field anywhere on the plate.

Except for the occurrence of Spathidium sp. and Lionotus sp. in the treated subsoil, the subsequent history of the cultures was of no particular interest.

A full list of the fauna observed in the four cultures is given in Table 1.

\section{DISCUSSION}

These observations demonstrate several important facts. First, as shown in Table 1, the number of species in the treated topsoil was greatly decreased by the steaming; there were only six species compared with twenty-five in the untreated topsoil. The treated subsoil, however, was little affected; twenty-one species were found as compared with twenty-two in the untreated subsoil. Secondly, the protozoan fauna of the steamed soils appeared some days after that of the untreated soils; there was a time lag in multiplication. Thirdly, protozoan activity in the steamed soils was far greater than in the untreated soils after the fauna had developed. This was particularly true of the steamed topsoil. The two principal ciliate species which occurred in this culture were Colpoda inflata and Oxytricha pellionella. After 11 days of cultivation these ciliates were present in very great numbers which have never been paralleled by any other soil culture in my experience. 
From these results it is obvious that while Russell \& Hutchinson were correct in surmising that the protozoan fauna would be drastically decreased by partial sterilization, they were in error when they attributed the heightened activity of the bacteria to the absence of protozoa. For not only are protozoa present in the treated soil but they are present in very great numbers and

Table 1. The protozoan fauna of steam treated and untreated greenhouse soil

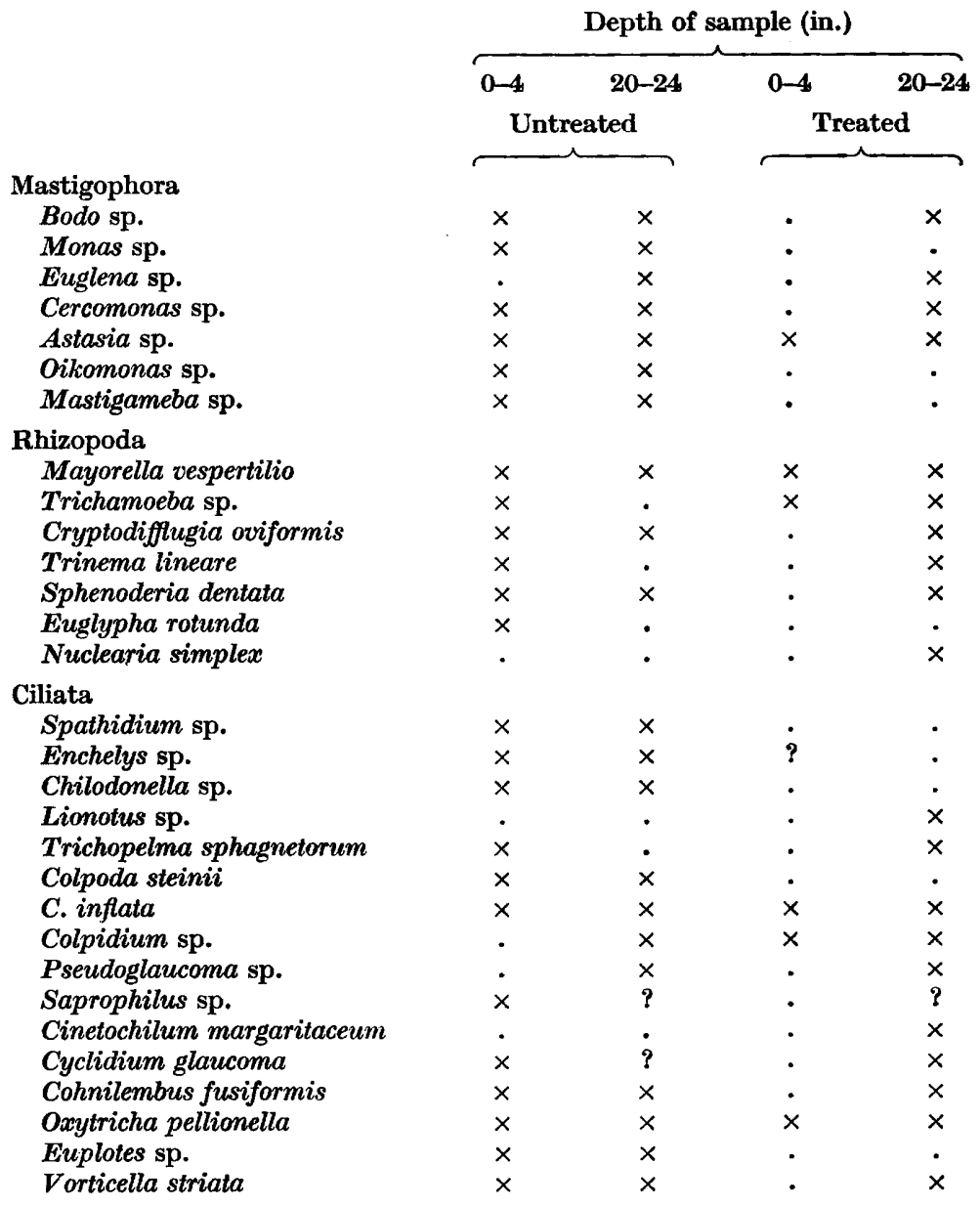

their activity is stimulated by partial sterilization just as much as the activity of the bacteria. Both show an initial inhibition followed by greatly enhanced activity of that part of the flora and fauna which is not killed by the steaming.

Kidder \& Stuart $(1939 a, b)$ found that the growth of Colpoda steinii was depressed in a mixed bacterial culture and that ultimately the ciliates died out. They also found that cyst formation was inhibited and that the ciliates which normally divide within a cyst membrane failed to do so. Singh (1941) confirmed the depressing effect which old culture filtrate had on the growth of 
Colpoda steinii even when adequate food was available. He showed that the toxic effect of the filtrate was removed by heating for $1 \mathrm{hr}$. at 70-80 . Brown \& Taylor (1938) found that excystment of Colpoda could be interrupted by returning cysts from their excystment medium to the medium in which they encysted. It appears that there is a thermolabile toxic factor in old culture fluid as a result of bacterial activity. The effect of steam sterilization is to remove this factor which will have the double effect of removing an excystment inhibitor and an inhibitor of ciliate growth. It will account therefore for the greatly stimulated growth of Colpoda spp. in the present cultures.

I am indebted to Dr E. B. Kidson of the Cawthron Institute for the opportunity to examine these soil samples.

\section{REFERENCES}

Anon. (1948). Partial sterilization. Soils \& Fert. 11, 357.

Brown, M. G. \& Taylor, C. V. (1938). The kinetics of excystment in Colpoda duodenaria. J. gen. Physiol. 21, 475.

KrDder, G. W. \& Stuart, C. A. (1939a). Growth studies on ciliates. I. The role of bacteria in the growth and reproduction of Colpoda. Physiol. Zoöl. 12, 329.

KIDder, G. W. \& Stuart, C. A. (1939b). Growth studies on ciliates. II. The food factor in the growth, reproduction and encystment of Colpoda. Physiol. Zoöl. 12, 341.

Russelx, E. J. \& Hutchinson, H. B. (1909). The effect of partial sterilization of soil on the production of plant food. J. agric. Sci. 3, 111.

SingH, B. N. (1941). The influence of different bacterial food supplies on the rate of reproduction in Colpoda steinii, and the factors influencing encystation. Ann. appl. Biol. 28, 65.

Singh, B. N. \& Crump, L. M. (1953). The effect of partial sterilization by steam and formalin on the numbers of amoebae in field soil. J. gen. Microbiol. 8, 421. 